\title{
FACTORS AFFECTING CAPITAL STRUCTURE ON REGIONAL COMPANY OF BKK RURAL BANKS IN SUKOHARJO REGENCY
}

\author{
Hadi Samanto \\ STIE-AAS, Central , Indonesia \\ Email: hadisamanto361@gmail.com
}

\begin{abstract}
The analysis result shows that sales positively affect the capital structure, it means that more sales increase is financed by debt. The asset structure does not positively affect the capital structure, it means that additional current assets are more financed from debt.Profitability has no negative effect on capital structure, it means that profits earned by the company can be partially replanted into the company to increase their own capital. Growth does not negatively affect the capital structure, it means a declining growth rate from year to year due to limited own capital, so asset growth is still financed by debt.Based on the F tests, it shows the sales, asset structure, profitability, growth affects the capital structure simultaneously. Coefficient of determination $\mathrm{R}^{2}$, Adjusted $\mathrm{R}$ Square value is obtained which shows sales, asset structure, profitability, and growth can explain the structure of capital, the remainder is explained by the residual variable or outside of this study.
\end{abstract}

Keywords: $\quad$ sales, asset structure, profitability, growth, and regression linear multiple.

\section{Introduction}

The company's capital needs can be met from internal sources namely funds which originating from within the company or external sources that are from outside the company. External sources derived from the owner or the participant are a separate component of capital, while those originating from the creditors are loan capital. Balance between total loan capitalor debt with the amount of capital itself is called the financial structure, while the capital structure is the balance between long-term debt and the amount of capital itself.

\section{Formulation of the problem}

hen viewed the amount of assets, deposits and savings of regional company of rural banks in Surakarta Residency have a fairly large scale operation.Therefore a decision on spending taken by the company's chairman will have a broad impact on the company's profits.

Ie main problem in this research is what factors affect the capital structure on 
International Journal of Economics, Business and Accounting Research (IJEBAR)

Peer Reviewed - International Journal

Vol-1, Issue-1, 2017 (IJEBAR)

ISSN: 2614-1280, https://jurnal.stie-aas.ac.id/index.php/IJEBAR

Regional Company of BKK rural banks in Sukoharjo Regency?
H4: Profitability has a significant negative effect on capital structure on at a local rural Bank BKK in Sukoharjo Regency;

\section{Objectives and benefits}

Based on the issues presented before, this study aims to analyze the factors that affect the capital structure Regional Company of Rural Bank in Sukoharjo Regency.

The results of this study can be used for leadership of Regional Company of rural banks in Sukoharjo Regency for the consideration in making decisions about capital structure.

\section{Hypothesis}

Based on the background and problems as well as the theoretical framework of factors affecting the capital structure, it can be proposed four alternative hypothesis as follows:

H1: Sales have a significant positive impact on capital structure at a local rural Bank BKK in Sukoharjo Regency;

H2: The structure of assets has a significant positive effect on capital structure at a local rural Bank BKK in Sukoharjo Regency;

H3: Growth has significant negative effect to capital structureat a local rural Bank BKK in Sukoharjo Regency;

\section{Journal}

me of the journals that support the research:

5.1 Ramezani (2002), in his article of growth, corporate profitability, and value creation, describes the relationship of the company's performance with the growth or sales made by the industry on investment. Most affect the compensation schemes of management and portfolio decisions or mutual funds. In this article described the relationship between growth and company performance with two main questions. First, the relationship between the ability to earn corporate profits. Second, economic value added and sales growth rate.

5.2 Scott (2006), in his article Loan Officer Turnover and Credit Availability for Small Firms, outlining empirical evidence of the role of loan officers running the facilities of small firms in relation to commercial banks that lend. If the loan officer uses soft information (such as an assessment of the nature of a person, information from consumers and material providers) to 
make loan decisions in other ways not only based on financial information (tax returns or financial statements)then the frequent turnover of credit officers have a bad influence on the availability of credit.

5.3 Craig (2006), in his article The Use of Nonqualified Structured Settlements in the Sale of Capital Assets, which outlines the sales structure is a unique opportunity to provide a new solution for a buyerand for people who want to sell capital goods or need it,in the sales process is taxed.

5.4 Lundsten (2006), in his article "Improve Your Profitability and Cash Flow: Critical steps to expedite Government Payments", which describes that research on business with the government is good for corporate cash flow, the situation can be seen from the entry of contracts made company. Each contract affects the cash flow of the company. Grouped into three phases in this contract include proposal requests and negotiations, performance, and final approval. A number of steps in the form of employment of several people, significantly improving cash flow. The processes and procedures described occur very complex and repetitive and are subject to learning curve (managers and process operators learn from experience on how to operate new technologies more effectively that can progressively reduce production costs). The more experience the less time is wasted. Such a way can significantly improve the ability to earn profit and cash flow.

5.5 Garrett (2006), in his article Building High-Performance buying and Selling Teams describes leadership skills especially in purchasing and selling with increasing product and services. Various levels of leadership related to skills for each level in the long term to achieve success. When a business group of professionals to solve the integrated purchasing and selling problems of the various products and services available, the ability to determine the timing and accuracy of deciding is to determine success. One of the most important to be a successful leaderand consistent in the field is when it can communicate sales and purchases.

5.6 Boot (2002), in its article Disagreement and Flexibility: A Theory of Optimal Security Issuance and Capital Structure describes flexibility as the economic concept and decision of securities selection and capital structure. Flexibility is the ability to make the best thought decisions when others disagree. The company's management assesses the flexibility because it makes the best trustworthy decision for shareholders without being blocked by people 
ISSN: 2614-1280, https://jurnal.stie-aas.ac.id/index.php/IJEBAR

who disagree. The amount of management flexibility has some time depending on how the company is levied. Debt offers little flexibility for own capital. However, flexibility is offered by the capital itself depending on outside parties where shareholders are in deciding to choose a management strategy. Capital itself offers the greatest flexibility when shareholders desire to approve the highest. The benefits of capital flexibility alone are high when stock prices are high. The choice of stock expenditure is void if the benefit of the stock is not better than the debt.

\section{Scope of the Research}

This research is an applied research that is done systematically and continuously to a problem with the aim to be used immediately for certain purposes. The topic of this research is about the influence of sales stability factor, asset structure, growth rate, and profitability to capital structure. The research was conducted in the Regional Company of Rural Bank of BKK Baki, Regional Company of Rural Bank of BKK Bendosari, Regional Company of rural bank BKK Grogol, Regional Company of Rural Bank of BKK Mojolaban, and rural bank BKK Sukoharjo.

\section{Analysis Method}

The research model is as follows:

$$
\begin{aligned}
& \mathrm{Y} \quad \mathrm{B} 0+\mathrm{B} 1 \mathrm{X} 1+\mathrm{B} 2 \mathrm{X} 2+ \\
& \mathrm{B} 3 \mathrm{X} 3 \mathrm{t}-1+\mathrm{B} 4 \mathrm{X} 4+\mathrm{e}
\end{aligned}
$$

, $\mathrm{B}_{2}, \mathrm{~B}_{3}, \mathrm{~B}_{4}$, show the regression keophisien for each variable. To determine whether the regression coefficient has been obtained meaningful or not, then at $95 \%$ confidence level is tested hypothesis coefficient of regression simultaneously and test of regression coefficient hypothesis individually.

\section{Classic Assumption Test}

:cause the data used is secondary data,then to determine the accuracy of the model needs to be tested on some of the classical assumptions underlying the regression model. Testing of classical assumption used in this research include multicolinearity, heteroscedasticity and autocorrelation. Each of these classical assumptions in detail can be explained as follows:

\subsection{Multicollinearity}

le first assumption test is multicolinearity test (multicollinearity) between independent variables that enter into the model.

$$
\text { Methods for diagnosing }
$$
multicollinearity were performed with a 
International Journal of Economics, Business and Accounting Research (IJEBAR)

Peer Reviewed - International Journal

Vol-1, Issue-1, 2017 (IJEBAR)

ISSN: 2614-1280, https://jurnal.stie-aas.ac.id/index.php/IJEBAR

predicted correlation (r) above 0.70 , and when the zero degree correlation was also high, but none or very few partial regression coefficients were individually statistically significant on the basis of conventional $t$ test (Gujarati, 2003 : 166).

In addition, we can also use the Variance Inflation Factor test which is calculated by the following formula: (Gujarati, 2003: 169)

VIF $=1 /$ Tolerance

If VIF is greater than 10, then between independent variable occurs multicolinearity problem.

\subsection{Heteroscedasticity}

The second test is heteroscedasticity used to determine whether or not heteroscedasticity with Glejser test is calculated by the following formula: (Gujarati, 2003: 187).

$$
\left[e_{i}\right]=ß_{1} X_{i}+v_{i}
$$

Wherein:

$\mathrm{e}_{\mathrm{i}}$ : residuals

$\mathrm{X}_{\mathrm{i}}$ : independent variable estimated to have close relationship with variance $\left(\sigma \mathrm{i}^{2}\right)$;

$\mathrm{v}_{\mathrm{i}}$ : error element.

If statistically found significant relationship,it can be concluded that there is heteroscedasticity in the variant of error; and vice versa.Besides, it can also be used Langrang Multiplier test (LM). The test procedure of Langrang
Multiplier is as follows (Setiaji, 2006:

47):

odels used:

$$
\mathrm{Y}=\mathrm{a}+\mathrm{b}_{1} \mathrm{X} 1+\mathrm{b}_{2} \mathrm{X}_{2}+\mathrm{b}_{3} \mathrm{X}_{3}+\mathrm{b}_{4} \mathrm{X}_{4}+\mathrm{e}
$$

1. Perform the above regression and compute the $\mathrm{e}$ and the estimated value of Y (Y predicted) $\hat{Y}$;

2. Squares the two variables above;

3. Now do the regression with the following model, e $2=a+b \hat{Y} 2+u$; $\mathrm{e} 2$ is the dependent variable, and $\mathrm{u}$ is an independent variable;

4. Calculate $\mathrm{R}$ from the above rescue regression;

5. Now multiply $\mathrm{R}$ obtained by the large sample $\mathrm{N}=\mathrm{R}^{2} \mathrm{xN}$;

6. Compare with the result with Chi Square table with one degree free (since we have one free variable) and alpha one percent;

7. The value of Chi Square is 9,2;

8. If $\mathrm{R}^{2} \mathrm{xN}$ is more than 9.2 then standard error has heteroscedasticity. Conversely, if $\mathrm{R}^{2} \mathrm{xN}$ is smaller than 9.2 then standard error (e) does not experience heterodasticity.

\subsection{Autocorrelation}

e third classical assumption test in a linear regression model is the presence or absence of autocorrelation. To test the existence of autocorrelation in the research, Durbin-Waston test (Gujarati, 2003: 192), where the required numbers in the method is dl (number obtained from the lower limit of DW table), du (number obtained from the DW table 
International Journal of Economics, Business and Accounting Research (IJEBAR)

Peer Reviewed - International Journal

Vol-1, Issue-1, 2017 (IJEBAR)

ISSN: 2614-1280, https://jurnal.stie-aas.ac.id/index.php/IJEBAR

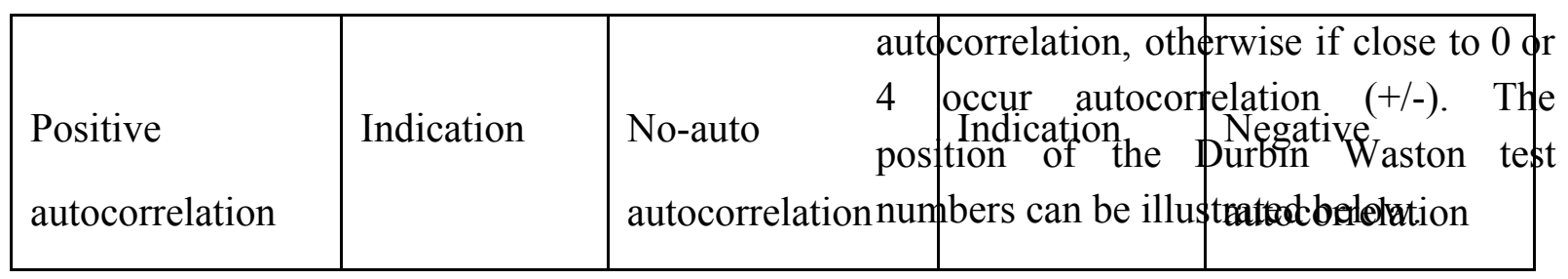

upper limit), 4 - dl, and 4 - du. If the value is

close to 2 then there is no

$\begin{array}{llllll}0 & \mathrm{dl} & \mathrm{du} & 4-\mathrm{du} & 4-\mathrm{dl} & 4\end{array}$

Picture: Position Number of Durbin Watson

\section{Hypothesis Testing}

Testing of the hypothesis is done in the following way:

9.1 Test of significance (real influence) of independent variables (Xi)to

\section{a. F-statistics test}

This test is used to test the significance of the effect of all independent variables together on the dependent variable.

This hypothesis is formulated as follows:

$\mathrm{H}_{1}: \mathrm{b}_{1}, \mathrm{~b}_{2}, \mathrm{~b}_{3}, \mathrm{~b}_{4} \neq 0$

This means that there is a significant influence together from independent variables $\left(\mathrm{X}_{1}, \mathrm{X}_{2}, \mathrm{X}_{3}, \mathrm{X}_{4}\right)$ to the dependent variable (Y).The F-count value can be searched by the formula (Gujarati, 2003: 259):

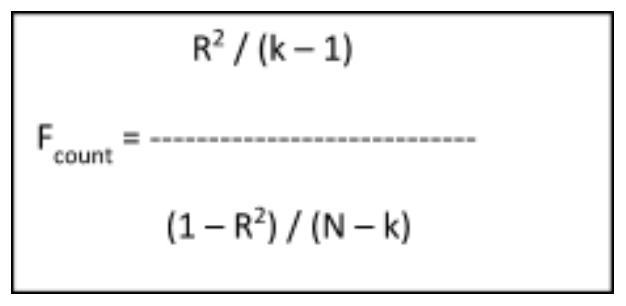

To determine the value of $\mathrm{F}$ table, the level of significance used is $5 \%$ degree of freedom $(\mathrm{df}=(\mathrm{n}-\mathrm{k})$ and $(\mathrm{k}$
-1); wherein " $n$ " is the number of observations, " $\mathrm{k}$ " is the number of variables including intercept, with the test criteria used are:

$\mathrm{F}_{\text {count }}>\mathrm{F}_{\text {table }}(\mathrm{a}, \mathrm{k}-1, \mathrm{n}-\mathrm{k})$, then $\mathrm{H}_{\mathrm{o}}$ is rejected; and

$\mathrm{F}_{\text {count }}<\mathrm{F}_{\text {table }}(\mathrm{a}, \mathrm{k}-1, \mathrm{n}-\mathrm{k})$, then $\mathrm{H}_{\mathrm{o}}$ is accepted.

\section{b. T-statistics test}

The significance test of coefficient (bi) is done by $t$-statistic (student- $t$ ).

It is used to test the partial regression coefficients of the independent variables. The hypothesis is formulated as follows:

$\mathrm{H}_{1}: \mathrm{b}_{1} \neq 0$

It means that there is a significant influence of independent variable $X_{i}$ against the dependent variable (Y).

The t-count value can be searched by the formula (Gujarati, 2003: 249):

Regression coefficient (bi)

$\mathrm{t}-_{\text {count }}=$

Standard Deviation bi 
To determine the value of $\mathrm{F}$ table, the level of significance used is $5 \%$ degree of freedom $(\mathrm{df}=(\mathrm{n}-\mathrm{k})$ and $(\mathrm{k}$ $-1)$; wherein " $n$ " is the number of observations, " $\mathrm{k} "$ is the number of variables including intercept, with the test criteria used are:

If $\mathrm{t}_{\text {count }}>\mathrm{t}_{\text {table }}(\alpha, \mathrm{n}-\mathrm{k}-1)$, then $\mathrm{H}_{\mathrm{o}}$ is rejected; and

If $\mathrm{t}_{\text {count }}<\mathrm{t}_{\text {table }}(\alpha, \mathrm{n}-\mathrm{k}-1)$, then $\mathrm{H}_{\mathrm{o}}$ is accepted.

To measure the dominance of independent variables (Xi) to the dependent variable (Y) is doneby looking at the standard beta coefficient numbers. For the test of the contribution of the ability to explain the independent variables simultaneously to the dependent variable can be seen of the coefficient of determination $\left(\mathrm{R}^{2}\right)$ multiple, but because the independent variable is more than two then used adjusted $\mathrm{R}^{2}$; where the value is between 0 $\leq 1$. It means that the value of $R^{2}$ which is getting bigger one is an indicator showing the greater ability to explain the change of independent variable $\mathrm{X}_{\mathrm{i}}$ to the dependent variable $Y$.

\section{Data Analysis}

After the measurement of the dependent variable namely the capital structure and independent variables of sales, asset structure, profitability, and growth rates, furthermore the analysis of the relationship of independent variables with the dependent variable.

\subsection{Hypothesis \\ Testing \\ and \\ Discussion}

a. Level of relationship or influence

e calculation result of regression coefficient on regional company of rural banks BKK in Sukoharjo Regency, obtained regression equation as follow:

$\mathrm{Y}=225,354+6,548 \mathrm{x}_{1}+3,756 \mathrm{x}_{2}-6$ $664 \mathrm{x}_{3 \mathrm{t}-1}-0,017 \mathrm{x}_{4}$

$$
\begin{aligned}
& (4,043) \quad(5,111)^{* *} \quad(0,518)^{* *} \\
& (-1,635)^{* *}(-0,005)^{* *} \\
& \mathrm{R}^{2}=0,741 \quad \mathrm{~F}=14,301
\end{aligned}
$$

\section{b. Hypothesis test}

, determine whether the regression coefficient that has been obtained above is meaningful or not then it does hypothesis test of the regression coefficient either simultaneously or individually.

11. Sales relationship, asset structure, profitability and growth rate simultaneously with capital structure.

$\mathrm{H}_{\mathrm{o}}: \mathrm{B}_{1}=\mathrm{B}_{2}=\mathrm{B}_{3}=\mathrm{B}_{4}=0$

$\mathrm{H} 1$ : at least one estimator $=0$

F count is 14,301 (attachment)

With a $95 \%$ confidence level, $F$ table $(0,05: 4: 20)$ is 2,87 . because $\mathrm{F}$ count $-\mathrm{F}$ table, then $\mathrm{H} 0$ is denoted. Means B1 is not equal to 0 . Therefore collectively the sales variables, asset structure, profitability and growth rate are able to explain the variation of capital structure.

12. Sales relationship with capital structure

$\mathrm{H}_{0}: \mathrm{B}_{1}=0$ that there is no relationship or influence of sales on 


\section{Vol-1, Issue-1, 2017 (IJEBAR)}

ISSN: 2614-1280, https://jurnal.stie-aas.ac.id/index.php/IJEBAR

capital structure. $\mathrm{H}_{1}: \mathrm{B}_{1 \neq 0}$ : that there is a significant relationship or influence of sales on capital structure. $\mathrm{T}$ count is 5,111 (attachment). Dwith a 95\% confidence level then $\mathrm{t}_{0,025}$ in the table is 2, 086. because $\mathrm{t}$ count $\mathrm{v}^{\bullet} \mathrm{t}$ table, then $\mathrm{H}_{0}$ is rejected. This means there is a relationship or the positive effect of sales variables on capital structure.

13. Relation of asset structure with capital structure

$\mathrm{H}_{0}: \mathrm{B}_{2}=0$

$\mathrm{H}_{1}: \mathrm{B}_{2} \neq 0$

$\mathrm{T}$ count $=0,518$ (attachment). At a $95 \%$ confidence leve lthen $t 0,025$ in the table is 2,086 . Since $\mathrm{t}$ count $-\mathrm{t}$ table $(0,518 \cdot 2,086)$ then $\mathrm{H}_{0}$ is accepted. It means there is no relationship or influence of variable structure of assets to the capital structure.

14. Relationship of Profitability with capital structure

$\mathrm{H}_{0}: \mathrm{B}_{3}=0$

$\mathrm{H}_{1}: \mathrm{B}_{3} \neq 0$

$\mathrm{t}$ count $=-1,635$ (attachment). At a $95 \%$ confidence level,then $t_{0,025}$ in the table is 2, 086. Because $\mathrm{t}$ count $\cdot \mathrm{t}$ table $(-1,635<2,086)$, then $\mathrm{H}_{0}$ is accepted. It means there is no relationship or negative influence of profitability variables on capital structure.

15. The relationship of growth rates with capital structure.
$\mathrm{H}_{0}: \mathrm{B}_{4}=0$

$\mathrm{H}_{1}: \mathrm{B}_{1} \neq 0$

$\mathrm{t}$ count $=-0,005$ (attachment). At a $95 \%$ confidence level, then 0,025 in the table is 2,086 . because $\mathrm{t}$ count $<$ $\mathrm{t}$ table $(-0,001<2,086)$, then $\mathrm{H}_{0}$ is accepted. It means there is no relationship or influence of growth rate variable on capital structure.

\section{c. Correlation coefficient}

sefficient of Double Determination $\left(\mathrm{R}^{2}\right)$ of 0 , 741 means independent variables (sales, asset structure, profitability and growth rate)collectively able to explain about $74.1 \%$ variation of the dependent variable (capital structure). Another $25.9 \%$ is influenced by variables not described in the model.

d. Interpretation of Regression Equations

has been proven from the regression coefficient hypothesis test simultaneously shows that sales variables, asset structure, profitability, and growth rates together have an influence to the capital structure.However, individual hypothesis testing is only sales variables that have significant influence on capital structure.

sspite testing the hypothesisindividuallyshowed no insignificant influence, but the relationship of these variables with the capital structure is consistent. This can be explained as follows:

1) Sales have a positive relationshipwith capital structure (indicated by positive regression coefficient), it means that more sales increase is covered by debt. 
2) Structure of assets have a relationship which is positive with capital structure (indicated by positive regression coefficient), meaning additional assets more smoothly in chargeof the source of funds derived from debt.

3) Profitability has a negative relationship with capital structure (indicated by negative regression coefficient), it means the profits obtained by the company, some of them can be reinvestedinto the company to increase their own capital.

4) The growth rate has a negative relationship with capital structure (indicated by negative regression coefficient). Actually the growth rate of Regional company of BKK rural bank in Sukoharjo DRegency from year to year decreased, but because of the limited capital itselfthen the growth of the company's assets is still always financed by debt.

\subsection{Classic Assumption Test}

The data used are secondary data, then to determine the accuracy of the model, it needs to be tested on some of the classical assumptions underlying the regression model. The classical assumptions tests carried out in this study include multicollinearity, heteroscedasticity and autocorrelation.The classical assumption test is detailed as follows:

\section{a. Multicollinearity}

To know the possibility of multicollinearity in the model need to do multicollinearity test, with SPSS for analysis, the results presented in collinearity diagnosis, and coefficient of correlation. Correlation coefficient between independent variables is not above 0.70 . The value of tolerance or inflation value of variance (VIF) is $1.486 ; 1,120 ; 1,700 ; 1.064$ far from 10 , it can be concluded independent variable does not occur multicollinearity.

\section{b. Heteroscedasticity}

the list of classical assumptions, the regression formula is obtained with the assumption that the vaiabel interference (error) or e, it is assumed to have a constant variant (range e more or less the same). If the variant of e is not constant, for example, enlarges or decreases at a higher $\mathrm{X}$ value, then the condition is not homoscedasti or experiencing heteroscedasticityk. To determine the occurrence of heteroscedasticity, then it needs heteroscedasticity test because the regression equation used is Ordinary Least Square (OLS). To determine whether or not heteroscedasticity, used the Langrang Multiplier method (LM).

:sults of data processing with SPSS. 15 got result of value of $\mathrm{R}$ square $=0,119$, sum $\mathrm{N}=25$, then $\mathrm{R}$ square $\mathrm{x}=0,119 \times 25=$ 2,975 . The multiplication result is smaller than Chi Square table $=9,2$, hence the symptoms of heteroscedasticity not exist or not significant.

\section{c. Autocorrelation}

te third classical assumption test in a linear regression model is the presence or absence of autocorrelation. To test the existence of autocorrelation in this research used Durbin - Waston test 


\section{Vol-1, Issue-1, 2017 (IJEBAR)}

ISSN: 2614-1280, https://jurnal.stie-aas.ac.id/index.php/IJEBAR

method. Calculations using SPSS. 15 obtained by Durbin - Waston $=1,801$ (in appendix).From the Durbin - Waston table it is known that $\mathrm{dl}=1.04$ and $\mathrm{du}=$ 1.77 ,for $\mathrm{k}=4$ and $\mathrm{N}=25$. The value of $\mathrm{du}=1.77$ while the value of $4-\mathrm{du}=4$ $1.77=2.23$.No autocorrelation occurs, if the Durbin - Waston value is between 1.77 to 2.23 . So in this autocorrelation test, there is no autocorrelation because the value of Durbin Waston is 1.801 .

From result of hypothesis test, both simultaneous testing ( $\mathrm{F}$ test), $\mathrm{t}$ esting individually $(\mathrm{t}$ test), as well as the classical assumption test consisting of multicollinearity test, heteroscedasticity test, or autocorrelation test can be concluded on the hypothesis presented in the introductory chapter as follows:

1. Sales proven have a positive influence on capital structure;

2. Structure of assetsproved to have no positive effect on capital structure;

3. The growth rate is provenhave no negative effect on the capital structure;

4. Proven profitabilityhas no negative effect on capital structure.

\subsection{Conclusions}

1. Judging from total assets and the number of outstanding credits from 2002-2006, it can be said that regional company of BKK rural banks has increased development. Increasing the amount of assets from the outstanding loans, then the regional company capital structure. BKK's Credit Bank also increased.
This shows the additional capital of more debt than the capital itself.

2. From the result of regression equation:

$$
\begin{aligned}
& \mathrm{Y}=225,354+6,548 \mathrm{x}_{1}+3,756 \mathrm{x}_{2}- \\
& 6,664 \times 3_{\mathrm{t}-1}-0,017 \mathrm{x}_{4} \\
& (4,043) \quad(5,111)^{* *} \quad(0,518)^{* *} \\
& (-1,635)^{* *}(-0,005)^{* *} \\
& \mathrm{Y} \quad=\text { capital structure } \\
& \mathrm{X}_{1}=\text { sales } \\
& \mathrm{X}_{2}=\text { asset structure } \\
& \mathrm{X}_{3 \mathrm{t}-1}=\text { profitability at } \mathrm{t}-1 \\
& \mathrm{X}_{4} \quad \text { growth rate }
\end{aligned}
$$

It can be concluded that the factors affecting capital structure are sales (outstanding credit).

While other factors: asset structure, profitability, and growth rate did not significantly affect the capital structure.

3. As a result of part of profit to the local government overpayment (55\% of profit after tax), the company can not form a reserve derived from profit. In other words although the company earns profit but the capital itself does not change much, so it will reduce the ability of Regional company of BKK rural banks to raise funds from the company itself.

\subsection{Suggestions}

1. Head of regional company of BKK rural banks applying paid-in capital 
to local government. Due to its own additional capital, the company's debt costs can be lower.

2. In drafting the budget planand corporate earnings, especially regarding the profit deposit to the local government, should be based on the profit achieved in previous years. So there will not be a profit deposit budget to local governments greater realization of profits earned.

3. Although the deposit to local governments already budgeted first, but in realization it should not exceed the amount that is right for the local governmentie $55 \%$ of profit after tax. If the deposit to the local government can be reduced it will enlarge the established reservesand by itself the capital becomes larger.

4. In an effort to reduce the cost of debt, need to be more active in extracting funds from savingsie by way of bank officials directly contact the savers in the market or in the villages. In addition, because regional company of $\mathrm{BKK}$ rural banks are owned by the local government, then egional company of BKK rural banks can dig the funds in the form of temporary depositfrom government agenciesboth within the local government as well as other agencies and private parties.

5. For the next researcher it can be used as a basis to examine other variables that affect the capital structure.

\section{REFERENCES}

Atmaja, Lukas.S, 2003, Manajemen

Keuangan(edisi revisi), Andi, Yogyakarta.

Brigham, Arnoud W.A, and Anjan V.Thakor, 2002, Disagreement and Flexibility: A Theory of Optimal Security Issurance And Capital Stucture, Colorado Summer Conference, Colorado.

Brigham, Eugene.F, and Joel F Houtson, 2004, Fundamental of Financial Management(tenth edition), Thomson South Western, Florida.

Djumahir, 2005, Pengaruh Tax Shield dan Non Tax Shield terhadap struktur modal dan Nilai Perusahaan, Unibraw Malang.

Garrett, Gregory, A; William, C. Pursch, 2006, Building High Performance Buying and selling Team, Contract Management, Vol 46, No pp 52-59.

Gitosudarmo, Indriyo, dan Basri, 2002, Manajemen Keuangan, BPFE-Yogyakarta, Yogyakarta.

Gujarati, Damodar.N, 2003, Basic Econometric(Fourth Edition), Mac.Graw Hill, Singapore.

Laundsten David, 2006, Improve Your Profitability and Cash Flow: Critical Step toExpedite Government Payment, Contract 
International Journal of Economics, Business and Accounting Research (IJEBAR)

Peer Reviewed - International Journal

Vol-1, Issue-1, 2017 (IJEBAR)

ISSN: 2614-1280, https://jurnal.stie-aas.ac.id/index.php/IJEBAR

Management, Vol 46, No 5, pp 20-24.

Ramezani, A.,Cyrus, Luc Soenen, 2002, Growth, Corporate Probability, and Value Creation, Financial Analysis Journal, Vol 58, No 6, pp 56-57.

Setiaji, Bambang, 2006, Panduan Riset Dengan Pendekatan Kuantitatif, Muhammadiyah University Press, Surakarta.

Scott, Jonathan, A., 2006, Loan Officer Turnover and Credit Availability for Small Firms, Journal of Small Bussiness Management, Vol 44, No 4, pp 544-562.

Sekaran, Uma, 2003, Research Method( A Skill - Building Approach), Fourth edition, John Willey\& Sons, Inc, Southern Illinois.

Sundjaja, Ridwan, S., Inge Barlian, 2003, Manajemen Keuangan Dua, Literata Lintas Media, Jakarta. 